\title{
高瀬川の塩分遡上に関する \\ 二次元分散モデルの開発 \\ DEVELOPMENT OF A TWO-DIMENSIONAL DISPERSION MODEL FOR THE SEAWATER INTRUSION IN TAKASE RIVER
}

\author{
赤穗良輔 1 - 石川忠晴 2 - 安河内美咲 3 - 鶴田泰士 4 \\ Ryosuke AKOH, Tadaharu ISHIKAWA, Misaki YASUKOUCHI, Yasushi TSURUTA \\ 1正会員 工博 東京工業大学 環境理工学創造専攻（干226-8502 横浜市緑区長津田町4259） \\ 2フェロー会員 工博 東京工業大学 環境理工学創造専攻（テ226-8502 横浜市緑区長津田町4259） \\ 3 学生会員 東京工業大学 環境理工学創造専攻（†226-8502 横浜市緑区長津田町4259番） \\ 4正会員 工博 (株)建設技術研究所（†330-0071 さいたま市浦和区上木埼 1-14-6）
}

This study proposes a new depth-averaged two-dimensional convection-dispersion model to investigate the seawater intrusion in well-mixed estuary. The new model considers both barotropic salinity flux and the baroclinic flux caused by weak salinity stratification. Liner salinity profile was assumed and physically meaningful baroclinic flux model was constructed base on hydrodynamic consideration. Then, model verification was carried out by simulating seawater intrusion in Takase River. In the new model, the salinity front arrived earlier and the peak value became stronger, which agrees better with the field data measured at Takase Bridge.

Key Words : Takase River, seawater intrusion, dispersion model, depth-averaged model, baroclinic

\section{1. 序論}

本研究で対象とする高瀬川は，図-1に示すように青森 県東部に位置する小川原湖と太平洋を結ぶ小河川である. 小川原湖はシジミやシラウオなど豊富な水産資源で知ら れる汽水湖だが，近年，水質の悪化が著しい．この原因 は，海水面上昇に伴う塩水侵入量増加により，嫌気化し た湖心部の高塩分層が膨張し，そこに溶解した物質の表 層への回帰速度が大きくなったためである.

そこで塩水侵入を制御するために長期間の塩水侵入現 象を簡略で，ある程度の精度が得られる数值モデルを用 いた検討が行われている. 高瀬川の塩水侵入は基本的に 強混合であるため，これまでは経験的一次元モデルが用 いられており，小川原湖へ侵入する塩分をよく再現でき ている1,2).ただし，強混合とはいえ塩分の鉛直分布を もっているため, 特に塩水の先端部では分散による塩水 遡上がある. 小川原湖へ侵入し蓄積していく塩水はこの 先端部分が大きく起因しているため，この分散を考慮し た数值モデルを導入することが今後求められる.

塩水流動は基本的に三次元だが，運動の空間スケール を大局的に夕ると, 密度成層に伴う傾圧効果に比較して 潮汐変動に伴う順圧変動の効果が支配的である. 一方,
高瀬川は中腹に広い浅瀬があるため，一次元モデルでは なく平面二次元モデルを用いる必要がある，そこで本研 究では，浅水流方程式で求めた順圧的流動に新たな塩分 の分散を考慮した数值モデル(分散モデル)により求めた 傾圧的流動を加えるという手法を開発した. 以上の考え に基づき数值モデルを構築し, 現地観測データと比較し て適用性を検討した。

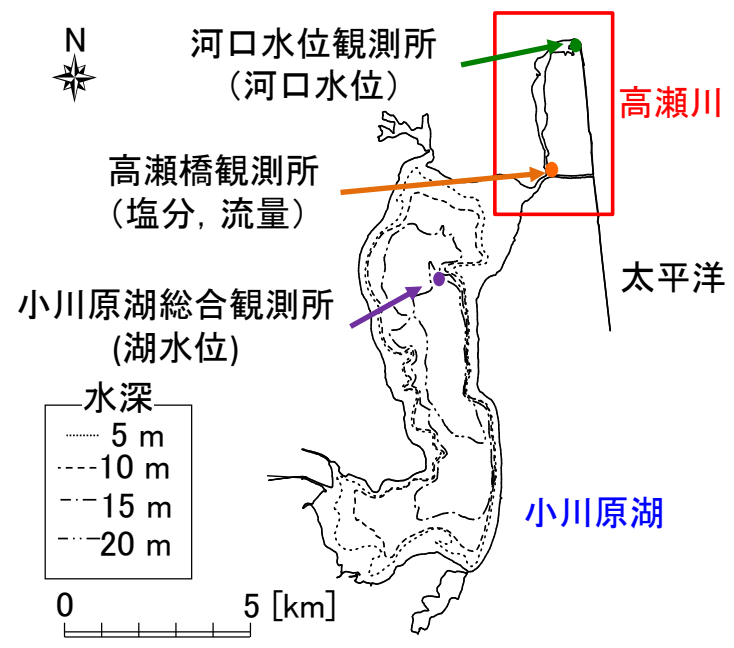

図-1＼cjkstart高瀬川の位置 

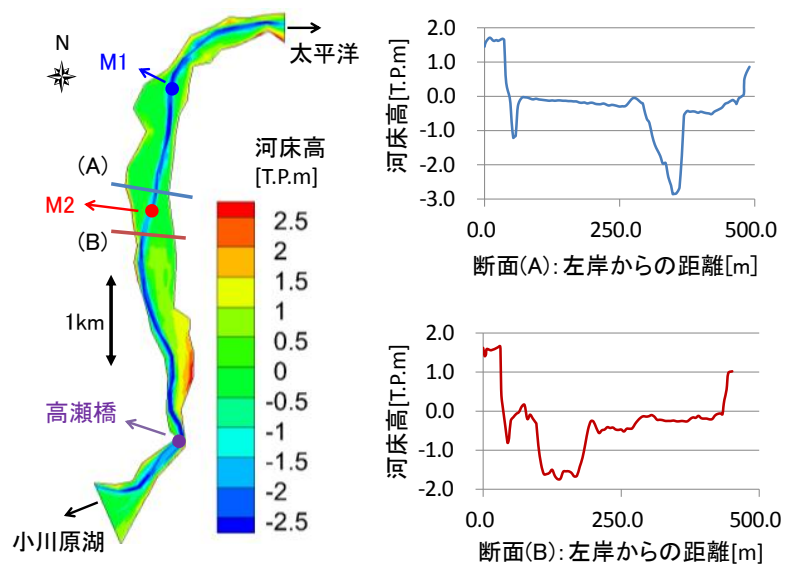

図-2＼cjkstart高瀬川の平面図および断面図の例
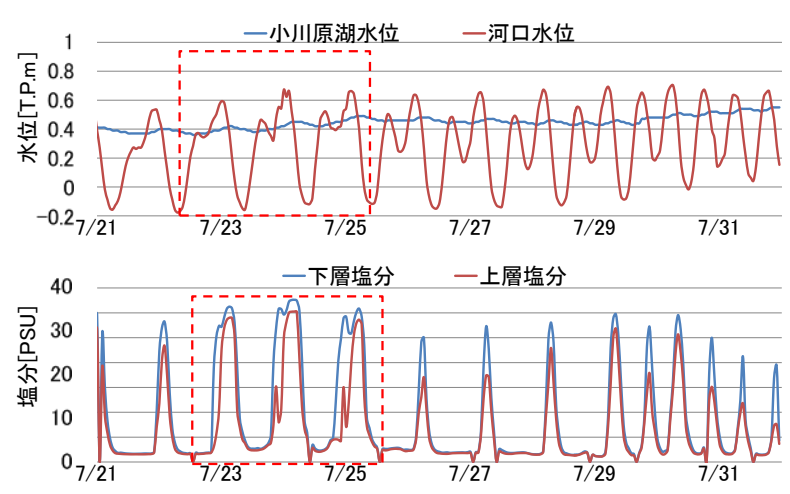

図-3 塩分侵入特性

\section{2. 高瀬川の概要}

図-2に高瀬川の平面図と断面図の例を示寸. 河道延長 は6.6km，澪の幅は約 $60 \mathrm{~m}$ ，干潮時の澪の水深は約 $2.5 \mathrm{~m}$ である．澪の両側は満潮時には水没する干潟となってお り、その最大幅は500m程度である。図-2に示寸高瀬橋 （河口から $5.5 \mathrm{~km} ） に$ 観測所が設置されており，水位と 流速流向の鉛直分布および上層・下層塩素イオン濃度が モニタリングされており, 流速および塩素イオン濃度か ら換算される流量および塩分より塩水遡上の様子を把握 することができる3゙．観測結果の例を図-3に示す。これ によれば，湖水位が比較的低い時期の大潮時に塩水が小 川原湖に流入する．また塩分は鉛直偏差を若干持ってい るものの, 高塩分水が大量に流入する場合は概水強混合 状態となっている．特に $2 つ の$ 満潮の間の干潮位が比較 的高い場合（例えば7月23日 25日，図-3 赤点線枠）に は高塩分が長時間継続し, 塩水が大量に湖内に流入して いると推測される.

\section{3. 塩分の移流分散モデル}

\section{(1) モデルの概要}

塩水流動を生じさせる圧力勾配は性質上 “順圧 (barotropic)” と“傾圧(baroclinic)” に分けられる. 順圧
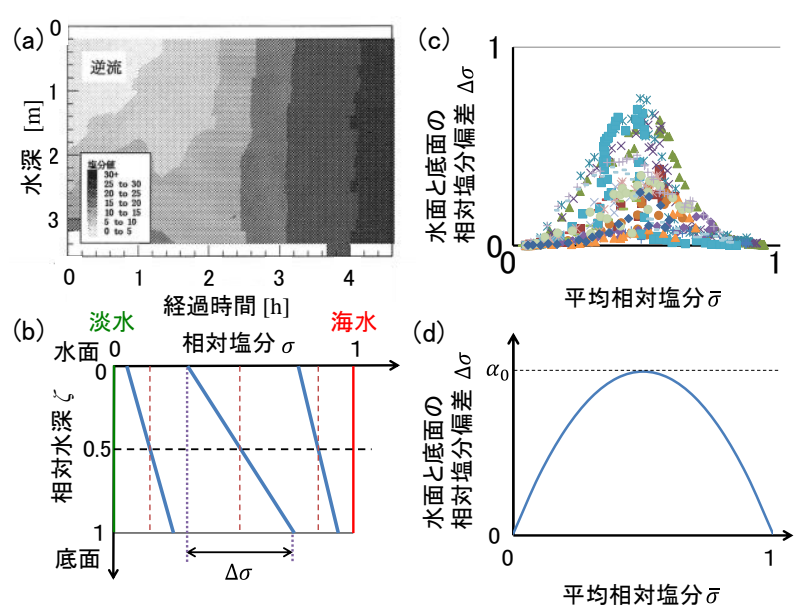

図-4 塩分鉛直偏差の仮定（a）高瀬橋におおける塩分の鉛直分布 の経時変化 (西田, 19933) より転載) (b) 直線的な密度分布の仮定, (c) 高瀬橋における相対平均塩分と相対塩分偏差の関係 (d) 水 面と底面の相対塩分偏差の仮定

とは水位差による全層的な圧力勾配であり，これによる 運動は浅水流方程式で記述できる。一方, 傾圧は密度の 鉛直分布の差異による断面内の圧力勾配である.

高瀬橋観測所のモニタリングデータによれば，高瀬川 の流量は湖水位と河口水位の差に概ね支配されている. このことから傾圧に比べて順圧による流動が大きいもの と考えられる. そこで本研究では, 浅水流方程式を用い て順圧的な流動を求めた後に, 傾圧的流動による “分散” を加えることとした. 本章では, 力学的考察に基づき傾 圧の効果を表現し，浅水流方程式で表される順圧的塩分 移流を補正するモデルを導出する.

\section{（2）塩分の鉛直分布}

傾圧は塩分の鉛直分布によって変化する．それを正確 に求めるには鉛直二次元ないし三次元モデルが必要とな る。しかし、高瀬川での塩水流入は, 図-4 (a) に示寸西 田らの観測結果 ${ }^{3}$ のように基本的に鉛直分布がなだらか な強混合であることから、塩分の鉛直分布を線形と仮定 することにより簡易なモデルを作成する.

本研究で用いる塩分の鉛直分布の概念図を図-4(b) に 示寸.ここで, 横軸は海水の塩分 $S_{0}$ に対寸る相対塩分 $\sigma=S / S_{0}$ で定義される相刘塩分の鉛直平均值 $\bar{\sigma}\left(=\bar{S} / S_{0}\right.$, $\bar{S}$ : 塩分の鉛直平均值)であり, 左側が淡水 $(\bar{\sigma}=0)$, 右 側が海水 $(\bar{\sigma}=1)$ である. また縦軸は水面からの深さ $z$, 水深 $h$ したとき， $\zeta=z / h$ で定義される相対水深である. 図-4 (b) に示すように淡水と海水の場合には塩分は鉛直 方向に一様となる. 一方, 中間密度の場合は下層の塩分 が上層に比較して大きくなる.

図-4 (c) に観測データより得られた $\bar{\sigma}$ と相対塩分偏差 $\Delta \sigma=\Delta S / S_{0}$ の関係の一例を潮汐ごとに色分けして示す. $\bar{\sigma}=0$ と 1 で $\Delta \sigma=0$, また偏差が大きい場合は概ね 20.5 で極 大となっている. そこで本研究では, $\Delta \sigma$ と の関係を 
式(2)のように放物線で近似する（図-4(d)）.

$$
\begin{gathered}
\sigma(\zeta)=\bar{\sigma}+\Delta \sigma(\zeta-1 / 2) \\
\Delta \sigma=4 \alpha_{0} \bar{\sigma}(1-\bar{\sigma})
\end{gathered}
$$

ここで， $\alpha_{0}$ は0〜1の範囲の值をとる偏差係数であり，值 が小さいほど水面と底面の塩分偏差が小さい，すなわち 混合が強い状態を表す。また、淡水密度 $\rho$ に対する塩水 の相対密度差を $\varepsilon=\Delta \rho / \rho(\Delta \rho$ は塩水々淡水の密度差 $)$ 之 し, 相対塩分と相対密度差の関係を線形で仮定する。

$$
\varepsilon=\varepsilon_{0} \sigma
$$

ここで， $\varepsilon_{0}$ は海水の相対密度差で0.031とする.

\section{（3）偏差流速のモデル化}

密度差によって生じる過剩圧力は $\rho g \varepsilon$ 之書けるので, これを水面から深さ $z$ まで積分することで，水圧の鉛直 分布 $P(z)$, さらにこの圧力を水面から深さ $z$ まで積分する ことによりその層に働く全水圧が求まる. 具体的にはそ れぞれ式(4)，(5)より得られる。

$$
\begin{gathered}
P(z)=\rho g \int_{0}^{z} \varepsilon d z=\rho g \varepsilon_{0} \int_{0}^{z} \sigma d z \\
F(z)=\int_{0}^{z} P d z
\end{gathered}
$$

本研究では，モデルを単純化するために，まず式(6)に示 寸重み関数を定義し, 上層と下層に作用寸る全水圧 $F_{u}$, $F_{d}$ を式(7)より与える（図-5(a)）.

$$
\begin{gathered}
w_{u}= \begin{cases}1 & 0 \leq \zeta \leq 1 / 2 \\
0 & 1 / 2 \leq \zeta \leq 1\end{cases} \\
w_{d}= \begin{cases}0 & 0 \leq \zeta \leq 1 / 2 \\
1 & 1 / 2 \leq \zeta \leq 1\end{cases}
\end{gathered}
$$

今，図-5(b)のように順圧分布を $P_{t}$ (赤線) ，実際の 圧力分布を $P$ (青線) とすると傾圧は $P_{c}=P-P_{t}$ （緑斜線） となる. 塩水層厚が縦断方向に変化するため上層では $P$ $<P_{t}$ となり右向きに傾圧が生じ，合力 $f_{u}$ (青矢印)は順圧 成分による合力 $f$ (赤矢印) に対して小さく，下層では $P>P_{t}$ となるので, 合力 $f_{d}$ は大きくなる. 本研究では, モデルを単純化するために, 傾圧成分を $\Delta f$ とし， $f_{u}, f_{d}$ を以下の様に表す(図-5(c)).

$$
\left\{\begin{array}{l}
f_{u}=\partial_{x} F_{u}=f-\Delta f \\
f_{d}=\partial_{x} F_{d}=f+\Delta f
\end{array}\right.
$$

式(8)を整理することで傾圧成分は式(9)より得られる.

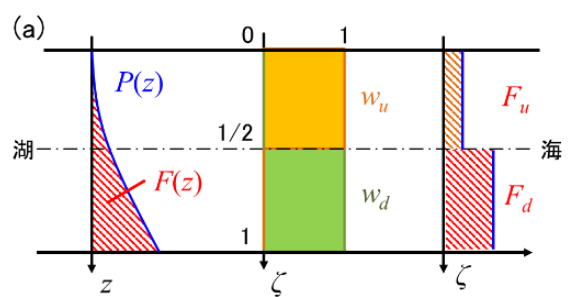

(b)

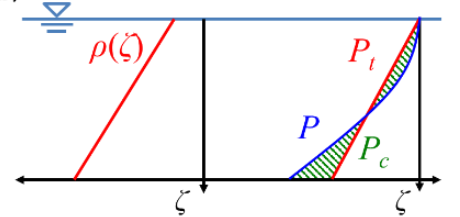

(c)
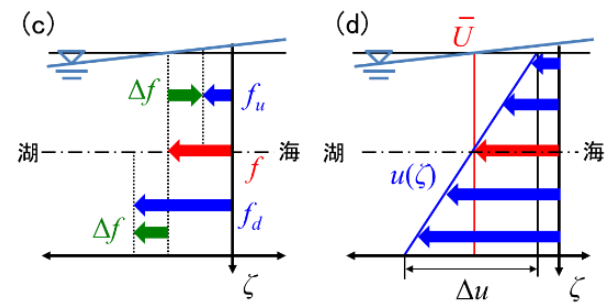

図-5 圧力分布のアンバランスによる速度残差の生成メカニズ ム（a）重み関数および全水圧 (b) 密度および水圧の鉛直分 布，（c）合力のアンバランス, (d) 流速の鉛直分布

$$
\Delta f=\frac{1}{2}\left(\partial_{x} F_{d}-\partial_{x} F_{u}\right)
$$

その結果，順圧により生じる平均流速 $\bar{U} に$ 対して，偏 差流速 $u$ 'が生じる，本研究では，流速の鉛直プロファイ ルを塩分プロファイルと同様に以下のような線形と仮定 する(図-5(d)).

$$
u(\zeta)=\bar{U}+u^{\prime}=\bar{U}+\Delta u(\zeta-1 / 2)
$$

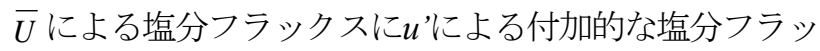
クスを加えることで, 移流分散モデルの構築を行う．層 内の傾圧成分 $\Delta f$ による力のアンバランスが界面での摩 擦によって解消されると仮定し，更に界面摩擦が偏差流 速 $\Delta u$ 2乗に比例すると仮定することで式(11)が得られ る. ここに㠶無次元のパラメータである.

$$
\rho \phi \Delta u^{2}=\Delta f
$$

式(1)，(2)で仮定した塩分の鉛直分布を式(4)に代入し， 式(5)〜(9)を順番に解くことで, 偏差流速 $\Delta u$ が式(12)より 得られる.

$$
\Delta u= \pm \sqrt{\frac{g \varepsilon_{0} h^{2}}{8 \phi}\left|\frac{\partial \bar{\sigma}}{\partial x}\right|}= \pm \sqrt{\frac{g \varepsilon_{0} h^{2}}{8 \phi S_{0}}\left|\frac{\partial \bar{S}}{\partial x}\right|}
$$

なお，正負の符号は $\partial \bar{S} / \partial x$ の符号と一致する．すなわ ち，上層の偏差流速は塩分の低い方から高い方へ，下層 では逆向きに向かうことになる. 


\section{（4）塩分の付加的フラックス}

平均流速および偏差流速によって生じる塩分フラック スは式(13)のように書かれる.

$$
\text { Flux }=\bar{S} \bar{U}+\int_{0}^{\zeta} s^{\prime} u^{\prime} d \zeta
$$

ここに $\bar{S}, \bar{U}$ は平均塩分および平均流速， $s^{\prime}, u^{\prime}$ は偏差 塩分を表す．式(1)，(9)を代入することで付加的フラッ クスは次式より得られる。

$$
\begin{aligned}
\int_{0}^{\zeta} s^{\prime} u^{\prime} d \zeta & =\int_{0}^{\zeta} \Delta u \Delta s(\zeta-1 / 2)^{2} d \zeta \\
& = \pm \frac{\alpha_{0} \bar{S}\left(S_{0}-\bar{S}\right)}{6 S_{0}} H^{2} \sqrt{\frac{g \varepsilon_{0}}{2 \phi S_{0}}\left|\frac{\partial \bar{S}}{\partial x}\right|}
\end{aligned}
$$

上式に含まれる2つのパラメータ で検討する。

\section{4. 塩分流動モデル}

\section{（1）全体モデル}

前章で述べたように，順圧による塩分の流動計算には 浅水流方程式を用いる．具体的には，水平方向の塩分偏 差による順圧の効果を考慮した次式より求める.

$$
\begin{gathered}
\partial_{t} h+\partial_{x} M+\partial_{y} N=0 \\
\partial_{t} M+\partial_{x}\left(\frac{M^{2}}{h}+\frac{g h^{2}}{2}(1+\varepsilon)\right)+\partial_{y}\left(\frac{M N}{h}\right) \\
=-g h(1+\varepsilon) \partial_{x} z_{b}-\frac{\tau_{b x}}{\rho}+\partial_{x}\left(h \tau_{u u}\right)+\partial_{y}\left(h \tau_{u v}\right) \\
\partial_{t} N+\partial_{x}\left(\frac{M N}{h}\right)+\partial_{y}\left(\frac{N^{2}}{h}+\frac{g h^{2}}{2}(1+\varepsilon)\right) \\
=-g h(1+\varepsilon) \partial_{y} z_{b}-\frac{\tau_{b y}}{\rho}+\partial_{x}\left(h \tau_{u v}\right)+\partial_{y}\left(h \tau_{v v}\right)
\end{gathered}
$$

ここに， $z_{b}$ は底面高， $\bar{U}, \bar{V}$ を $x, y$ 方向の鉛直平均流速 としたとき， $M, N$ は $x, y$ 方向の線流量（単位幅あたりの 体積フラックス） で $\bar{U} h, \bar{V} h$ に等しい. また $\tau_{b x}, \tau_{b y}$ は 底面せん断応力, $\tau_{u u}, \tau_{u v}, \tau_{v v}$ は平均流に対して水深 平均を施したレイノルズ応力であり，本論文ではそれぞ れマニングの式および0方程式モデルにより与えた.

塩分の輸送方程式は次式で書かれる。

$$
\partial_{t}(h \bar{S})+\partial_{x}\left(M \bar{S}+F_{x}\right)+\partial_{y}\left(N \bar{S}+F_{y}\right)=0
$$

ここで $M \bar{S}$ と $N \bar{S}$ がそれぞれ $x, y$ 方向の順圧による塩分 フラックスであり， $M, N$ は式(15)より得られた值を用 いる. また, $F_{x}, F_{y}$ は前章で求めた傾圧による塩分の付 加的フラックスであり，それぞれ次式より求められる.

$$
\begin{aligned}
& F_{x}= \pm \frac{\alpha_{0} \bar{S}\left(S_{0}-\bar{S}\right)}{6 S_{0}} h^{2} \sqrt{\frac{g \varepsilon_{0}}{2 \phi S_{0}} \mid \partial_{x} \bar{S}} \mid \\
& F_{y}= \pm \frac{\alpha_{0} \bar{S}\left(S_{0}-\bar{S}\right)}{6 S_{0}} h^{2} \sqrt{\frac{g \varepsilon_{0}}{2 \phi S_{0}} \mid \partial_{y} \bar{S}}
\end{aligned}
$$

\section{（2）横断方向の塩分流動のモデル化}

図-2に示したように，高瀬川の中下流部には広い浅瀬 があり, 河道縦断方向への塩分輸送に大きな影響を与え ている ${ }^{4}$. 塩水流は主に澪を遡上するが，澪の塩分が表 層一上昇すると干潟に塩水が流入する。この過程では澪 と干潟の高低差が塩水流動に影響を及ぼし，澪表層の水 のみが干潟に流入する (図-6(a))。

本研究では，この過程を以下のように簡略化して取り 扱った. 図-6(b) に示寸ように浅瀬の水深を $h_{1}$, 澪の水 深を $h_{2}$ とし，それぞれの鉛直平均塩分を $\bar{S}_{1}, \bar{S}_{2}$ とする. 密度効果のために澪の深部にある高塩分水は干潟に侵入 できない．そこで零と干潟の間の流動に関与する澪の 塩水は干潟底面より上の部分であると考え，塩分の鉛直 平均值を $\bar{S}_{2}^{\prime}$ とみなして前節と同様の計算を行う。すな わち式(19)で変換する.

$$
\bar{S}_{2}{ }^{\prime}=\frac{1}{\zeta_{0}} \int_{0}^{\zeta_{0}} S d \zeta
$$

ここに, $\zeta_{0}=h_{1} / h_{2}$ は干潟に対する澪上層の相対水深であ る. 式(17)，(18)の $\partial \bar{S} / \partial x$ および $\partial \bar{S} / \partial y$ を式(19)より 求められる上部の平均塩分を用いて算出する.

\section{（3）数値解析手法}

本研究では，文献5)と同様に三角形格子における有限 体積法を用いて基礎方程式の離散化を行った. Godunov 系統の計算手法を採用しており, 特性線に沿って波動方 程式を分解し，波の風上方向を考慮した定式化を行うこ とで，安定かつ高精度に移流計算を行うことができる. (a)

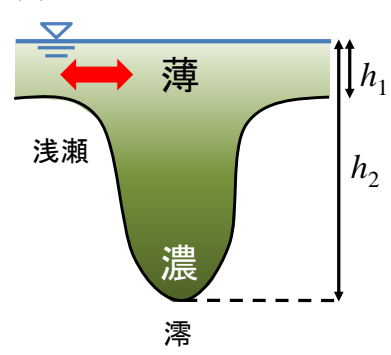

(b)

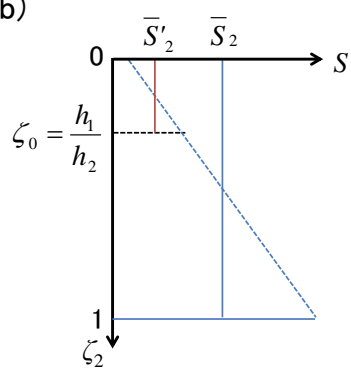

図-6 横断方向の塩分流動特性 (a) 横断方向断面図, (b) 分散モデルの澪における塩分の取り扱い 


\section{5. モデル検証}

本モデルの妥当性を検証するため, 高瀬川を遡上する 塩分流動計算を行った．対象として表-1に示寸期間につ いて行った.これらの期間は高瀬橋観測データが前後で 連続的に得られており, かつ通過塩分が多い期間である.

\section{(1) 計算条件}

図-7 (a) に計算領域および計算格子を示す。計算格子 数は66369とした。両端の境界条件には，図-7 (b) に示寸 ような河口水位（赤線）と小川原湖湖心水位（青線）を 与えた. 各水位はそれぞれ河口観測所と小川原湖観測所 で年間を通じて1時間ごとに観測されている．初期水位 は小川原湖水位, 河道内の初期流速は静止状態とし, 初 期塩分は0.9[PSU], 下流端は全ての期間について河口付 近の塩分として文献のを参考に33.0[PSU]とした．なお， 計算時間間隔は, 解の収束性を考慮して 0.25 秒とした.

\section{（2）観測データを用いた偏差係数の設定}

式(14)に示寸ように，傾圧による塩分の付加的フラッ クスには $\phi$ と $\alpha_{0}$ とらう2つのパラメータが含まれている.

表-1 計算期間

\begin{tabular}{|l|l|}
\hline (a) & 1999年1月26日0:00 1999年1月28日0:00 \\
\hline (b) & 2002年8月4日12:00 2002年8月7日12:00 \\
\hline (c) & 2005年8月15日12:00 2005年8月18日12:00 \\
\hline (d) & 2006年1月14日0:00 2006年1月17日0:00 \\
\hline
\end{tabular}

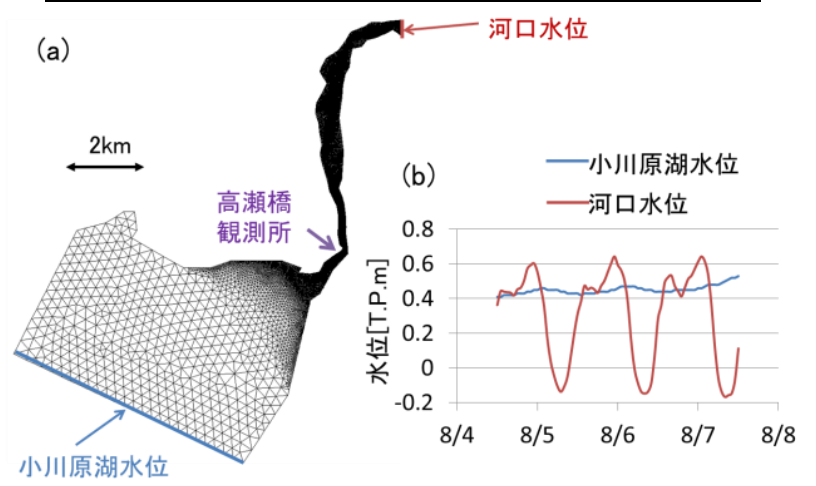

図-7 計算条件 （a) 計算領域，(b) 境界条件

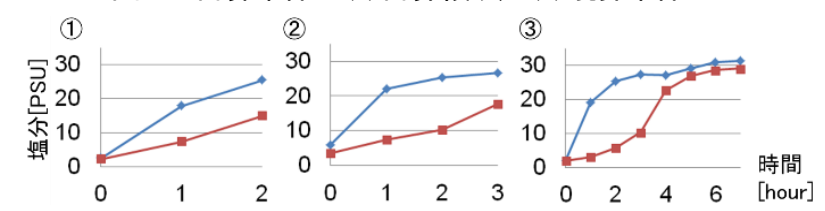

(a) 上げ潮時における上層と下層の塩分の時間変化例
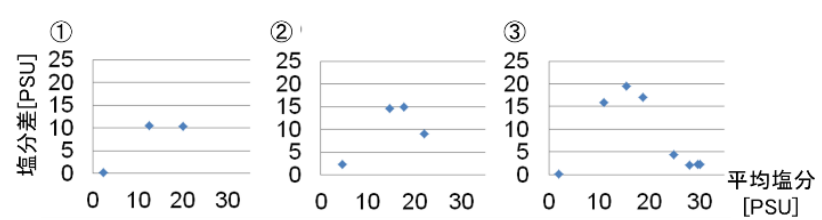

(b) 上層と下層の平均塩分と塩分差の関係

図-8＼cjkstart観測データによる偏差係数 $\alpha$ 。の設定
ここで， $\alpha_{0}$ は混合の強弱を表すパラメータとなっている ため, 大潮・小潮などの潮位変化に依存すると考えられ る. そこで本研究では, 以下の様に観測データを用いて $\alpha_{0}$ の回帰式を作成する.

まず，高瀬橋観測所で観測されている上層と下層の塩 分(図-3) を用いて以下の様に $\alpha_{0}$ を求めた。 図-8 (a)のよ うに，遡上時の上下層の平均塩分と塩分差の関係を整理 すると図-8(b)に示寸ようになり，式(2) と類似の性質を 示す. 寸なわち中央でピークをとり両端でゼロとなる. そこで，上下層の塩分差が比較的大きい潮汐を対象とし て，式(2)を用いて各潮汐での $\alpha_{0}$ を求め，また対応寸る潮 汐の満潮時の湖水位と河口水位の差の最大值 $\Delta \mathrm{He}$ との 相関性を調べた.

ここで，高瀬橋での観測データは欠損および異常值と なる期間があるため，比較的連続的にデータが得られて いる2003〜2006年の高塩分が長時間継続した潮汐を対象 として求めた. 得られた結果を図-9に示す. 年度ごとに 色を分けて表示しているが，いずれの年度についても $\Delta$ Heに対して負の相関があることが明らかである．得ら れた式(20)の線形回帰式を用いることで, 高瀬川におけ る塩水遡上時の混合の強さと潮位変化の関係性をある程 度表すことができる．回帰結果を図-10に示す．

$$
\alpha_{0}=-1.4748 \times \Delta H e+0.6771
$$

なお，藤原ら》によって行われた現地観測より得られ た高瀬橋断面の水理特性によると, 逆流から順流に転じ る際に, 上層の塩分が減少し2層構造になることが示さ れている，そこで，本検証では湖水位が河口水位より低 い場合は，式(20)の最大值とした。.また，もう一つのパ ラメータ $\phi$ は数值計算結果が観測值に近くなるように経 験的に定めた. その結果 $\phi=0.0018$ を得た.

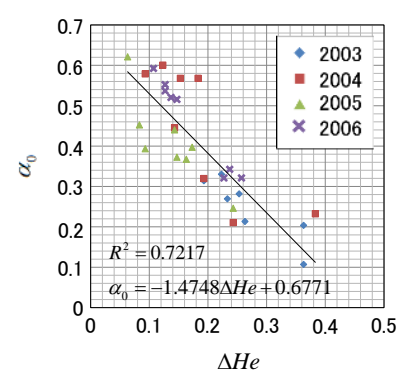

図-9 $\Delta H e-\alpha_{0}$ の関係

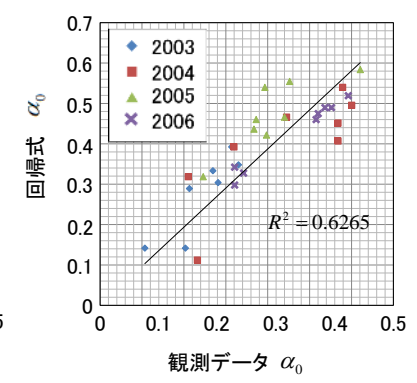

図-10 $\alpha_{0}$ の回帰結果

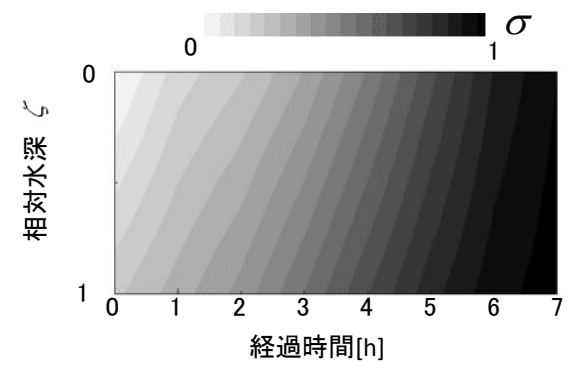

図-11高瀬橋における塩分の鉛直分布の経時変化 


\section{（3）高瀬橋における流量および塩分の比較}

図-11に式(1)を用いて求めた高瀬橋における塩分の鉛 直分布の経時変化の計算結果の一例を示寸．塩水の先端 部では鈆直勾配が大きく，塩分が濃くなるにつれ勾配が 小さくなっており，図-4（a)に示した観測データが持つ 特徵を二次元モデルを用いてある程度再現できている.

次に, 図-12に各計算期間における高瀬橋での流量お よび塩分の1時間ごとの時間変化を示す．赤線が観測 データ, 青線が分散モデル, 緑線が分散なしの浅水流モ デルによる計算結果を示す．ただし，流量は両モデルの 結果がほぼ重なるため, 分散モデルの結果のみ示寸。ま た，塩分の観測值には上層と下層の平均值を用いた。

浅水流モデルと比較して分散モデルは，いずれの期間 についても塩分流入の各ピークの值が高くなり，また侵 入し始める時刻が早くなっており, 観測結果により近い 值となっている. これは，本研究で用いた付加的フラッ クスによる分散の効果が，小川原湖に侵入する塩水の先 端部において適切に働いていると考えられる.

また，2006年の浅水流モデルでは，1月15日以降に塩分 が引いていないことが分かる。これは，逆流時に高い

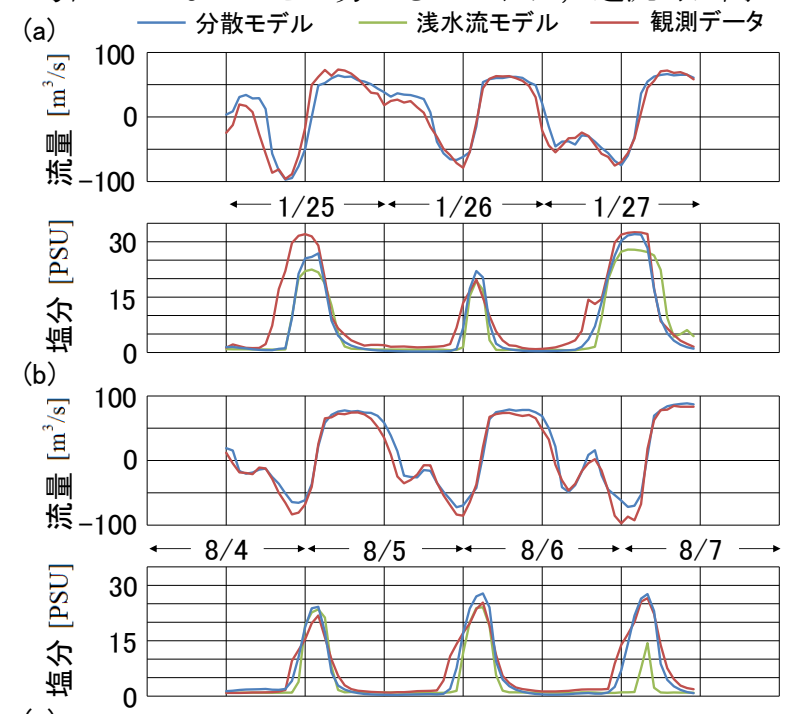

(c)

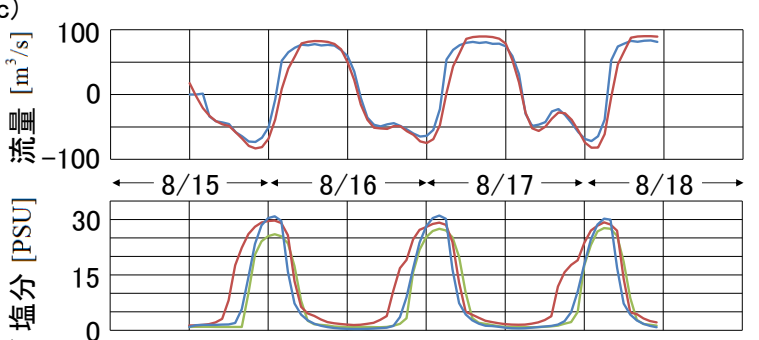

(d)

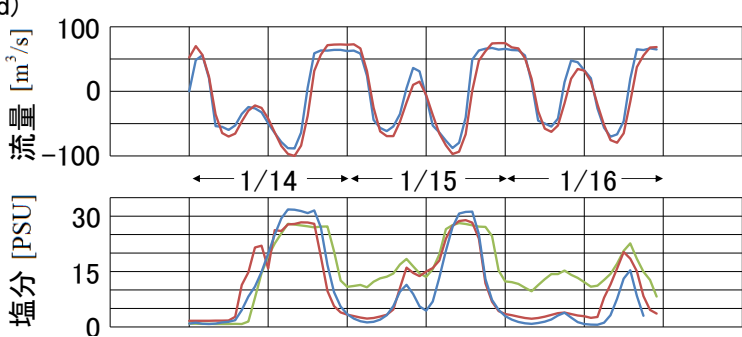

図-12 流量および塩分の観測結果と計算結果の比較

（a）1999年1月， (b) 2002年8月，(c) 2005年8月，(d) 2006年1月
塩分が浅瀬に侵入し，順流時にも完全にフラッシュされ なかったためである.この点についても改善できている ことから，本研究で提案した横方向への塩分流動につい てのモデル化が効果的に働いていることが示された.

以上より，本モデルは長期間の計算が可能な浅水流モ デルと同程度の計算負荷で分散による塩水遡上を考慮で きることから，高瀬川から小川原湖へ侵入する塩水入 ラックスを予測するのに非常に有効であると考えられる.

\section{6. 結論}

本研究では，高瀬川の流動特徵を考え，塩分鉛直偏差 を加えた新たなモデルの構築する方法を検討した. 本研 究を通じて得られた結論を以下に示寸.

1. 高瀬川の塩水流動において順圧の影響が傾圧の 影響を上回ることに着目し，浅水流方程式で順 圧下の流動を求めた後に傾圧の影響を考慮した 分散モデルで補正を加え塩分の移動を表現した。

2. 高瀬川の中下流部の広い浅瀬が河道縦断方向一 の塩分輸送に大きな影響を与えていることを考 慮し，鉛直塩分偏差を用いて，さらに横断方向 の分散モデルを加えた.

3. 高瀬橋における上下層の塩分偏差と, 各潮汐の 満潮時の湖水位と河口水位の差の最大值との間 に高い相関性があることを明らかにし，観測 データを用いた偏差係数の設定方法を提案した。

4. 高瀬橋における現地観測データと流量, 塩分の 時間変化を比較したところ, 新たな分散モデル を用いることで，小川原湖へ侵入する塩水の先 端部における分散を効果的に考慮できることが 明らかになった。

\section{参考文献}

1）鶴田泰士, 石川忠晴, 西田修三, 藤原広和, 村井禎美 : 小川 原湖への海水侵入現象に関わる水理データの整備と復元，水 文・水資源学会誌，Vol.14、No.1、pp.13-26,2001.

2) 石川忠晴, 木下隆史, 赤穂良輔 : 小川原湖の長期塩分状態変 化モデルの基礎的検討，河川技術論文集，第19巻，pp.549554, 2013.

3）西田修三，中辻啓二 : 緩混合河川における流量と塩分輸送量 の算定, 水工学論文集, 第43巻, pp.869-874, 1999.

4）成田舞, 石川忠晴, 藤原広和, 和光一紀 : 高瀬川中下流部の 浅瀬が塩水遡上に及ぼす影響について, 水工学論文集, 第 47 巻, pp.955-960, 2003.

5) 赤穂良輔、石川忠晴: 平成23年東北地方太平洋沖地震津波に おける，水工学論文集，第56巻，pp.1543-1548, 2012.

6) 成田舞 : 青森県高瀬川中下流部の浅瀬が塩水遡上に及ぼ寸影 響について, 東京工業大学, 修士論文, 2003.

7) 藤原広和, 田中博通 : 高瀬川感潮域の現地観測による水理特 性について, 水工学論文集, 第37巻, pp.171-176, 1993.

(2013. 9. 30受付) 